\title{
Comparative study of the stability of free and modified papain incorporated in topical formulations
}

\author{
Claudinéia Aparecida Sales de Oliveira Pinto ${ }^{1, *}$, Patricia Santos Lopes ${ }^{2}$, Fernanda Daud Sarruf', \\ Bronislaw Polakiewicz ${ }^{3}$, Telma Mary Kaneko ${ }^{1}$, Andre Rolim Baby ${ }^{1}$, Maria Valéria Robles Velasco ${ }^{1}$
}

${ }^{I}$ Department of Pharmacy, Faculty of Pharmaceutical Sciences, University of São Paulo, ${ }^{2}$ Departamento de Ciências Exatas e da Terra, Instituto de Ciências Ambientais, Químicas e Farmacêuticas da Universidade Federal de São Paulo, ${ }^{3}$ Department of Pharmaceutical and Biochemical Technology, Faculty of Pharmaceutical Sciences, University of São Paulo

\begin{abstract}
Papain is an enzyme used in topical formulations as a proteolytic debriding agent for the treatment of open, extensive wounds and burnings. It is also employed as an enhancer for cutaneous permeation of active compounds, chemical peeling and as a progressive depilatory agent. The stability of formulations containing enzymes is not easy. In this research, papain was modified with polyethylene glycol in order to increase the stability of the formulations. The comparative Normal Stability Testing of the topical formulations containing unmodified and modified papain showed that the modified variety presented with a differentiated profile under the adopted temperature conditions $\left(5.0 \pm 1.0{ }^{\circ} \mathrm{C} ; 22.0 \pm 2.0{ }^{\circ} \mathrm{C}\right.$; $40.0 \pm 2.0^{\circ} \mathrm{C}$ ). The most suitable condition for non-modified papain were $5.0 \pm 1.0^{\circ} \mathrm{C}$ and, for modified papain, they were $22.0 \pm 2.0^{\circ} \mathrm{C}$. These results confirmed the higher stability of modified papain compared to free papain, as well as its potential to be applied in topical formulations.
\end{abstract}

Uniterms: Papain/use in topical formulations. Papain/normal stability test. Poliethylene glycol/use. Topical formulations/development. Papain/enzimatic activity.

\begin{abstract}
A papaína é uma enzima utilizada em formulações tópicas como agente proteolítico debridante no tratamento de lesões abertas de grande extensão e queimaduras. É, também, empregada na pele íntegra como agente promotor da permeação cutânea de princípios ativos, peeling químico e como agente depilatório progressivo. A estabilidade de formulações contendo enzimas não é facilmente alcançada. No presente trabalho realizou-se a modificação da enzima com polietilenoglicol, visando maior estabilidade das formulações. A realização do Teste Estabilidade Normal comparativo entre as formulações contendo as formas da enzima não modificada e modificada demonstrou que a última apresentou um perfil de estabilidade diferenciado, nas diferentes condições $\left(5,0 \pm 1,0{ }^{\circ} \mathrm{C} ; 22,0 \pm 2,0{ }^{\circ} \mathrm{C} ; 40,0 \pm 2,0^{\circ} \mathrm{C}\right)$. A condição de $5,0 \pm 1,0{ }^{\circ} \mathrm{C}$ foi a mais adequada para a formulação contendo papaína não modificada enquanto a $22,0 \pm 2,0^{\circ} \mathrm{C}$ foi indicada para aquela contendo a forma modificada. Estes resultados confirmaram o aumento da estabilidade da papaína modificada comparada com a livre e seu potencial de aplicação em formulações de uso tópico.
\end{abstract}

Unitermos: Papaina/uso em formulaçãoes tópicas. Papaina/teste de estabilidade. Polietilenoglicol/uso. Formulações tópicas/desenvolvimento. Papaina/atividade enzimática.

\section{INTRODUCTION}

The use of enzymes in cosmetic formulations has been widely disseminated in the last years. Proteolytic enzymes, such as papain and bromelain, have been ap-

*Correspondence: C. A. S. O. Pinto. Departmento de Farmácia, Faculdade de Ciências Farmacêuticas, Universidade de São Paulo, Av. Prof. Lineu Prestes, 580, 05508-900 - São Paulo - SP, Brazil. E-mail: clausal@usp.br plied in Cosmetology for chemical peeling, depilatory preparations and as penetration enhancers (Lopes et al., 2003; Traversa et al., 2003).

The action of papain on the skin has been investigated by many researchers, who found positive results regarding hydration, penetration enhancement of active compounds and a decrease in hair growth velocity (ElKadi et al., 2001; Sim et al., 2003; Lopes et al., 2008; Traversa et al., 2003). 
Papain is an enzyme originated from the latex of the adult green papaya leaves and fruit, Carica papaya Linn. It is a mixture of proteins that contains a combination of papain and chymopapain (proteolytic enzymes that hydrolyse polypeptides), starch and esters, especially in bondings involving alkaline amino acids, leucine or glycine, producing peptides with low molecular weight. The term refers not only to the dry rough latex, but also to the crystalline enzyme. Papaya trees are cultivated on most tropical countries (Merck Index, 2006; Martindale, 2009).

One of the limiting factors for the use of papain in topical formulations is its low chemical stability. The enzymatic activity of papain may be influenced by environmental conditions such as temperature, light, oxygen, humidity and packing. The enzyme is more stable and active in $\mathrm{pH}$ 5.0-7.0 (Sasmito, Demeester, Bracke, 1982; Sim et al., 2000). The stability of the enzyme (both as a solid and incorporated in semi-solid formulations) has been investigated at different temperatures and results have confirmed the decrease in its activity with the temperature increase (Arnon, 1970; Traversa et al., 2003; Szabó et al., 2006).

Kang \& Warner (1974) researched the effect of $\mathrm{pH}$ on the activity of papain. The combined actions of $\mathrm{pH}$ and temperature on the stability of this enzyme have suggested a slight reduction at $\mathrm{pH} 5.0$; some loss at 7.0 and significant reduction at $\mathrm{pH} 9.0$, especially at $70^{\circ} \mathrm{C}$.

An alternative to increase papain stability involves modifying enzyme structure in order to protect its active hydrolysis site. There are many methods to modify the stability of enzymes, considering their specific action. There have been many attempts to stabilize papain structure, such as: covalent bondings, interaction with immobilized ion metal, insolubilization in glutaraldehyde, imobilization in agarose, biopolymer, covalent bondings with polyether sulphone, coupling with polymeric sucrose, modification with succinic anhydride, simple absorption in Celite ${ }^{\circledR}$, ionic absorption in CM-cellulose (cationic ion-exchange resin) and QAE-Sephadex ${ }^{\circledR}$ (anionic ion-exchange resin), and cross-linked covalent bonding (Sim et al., 2000; Afaq, Iqbal, 2001; Li et al. 2010).

Modifications in enzyme structure may lead to alterations when it is added to pharmaceutical or cosmetic formulations. The behavior of free papain in topical formulations is reported in the literature. Velasco et al. (1999) have studied the stability of papain incorporated in gel formulations at different temperatures and they found that the formulation presented higher stability when kept under refrigeration. According to the Stability Test, the enzyme kept approximately $70 \%$ of its initial activity for nearly two months.

The stability study supplies information concerning product behavior during a given period of time and under the environmental conditions it may undergo. Therefore, Preliminary and Accelerated Stability Tests are performed at different temperatures, relative humidity and lighting conditions that accelerate the degradation of formulations. These tests supply information to select the best preparation to undergo the Normal Stability Test for 90-120 days at the following temperatures: environmental temperature $\left(20.0\right.$ to $\left.25.0 \pm 2.0^{\circ} \mathrm{C}\right)$, high temperatures $(37.0 ; 40.0 ; 45.0$ and $\left.50.0 \pm 2.0^{\circ} \mathrm{C}\right)$, and low temperatures $(-5.0 ; 5.0$ and $\left.10.0 \pm 2.0^{\circ} \mathrm{C}\right)($ Baby et al., 2004; Brasil, 2004)

Some parameters evaluated in the Stability Tests of formulations for topical use, in general, include: organoleptical characteristics (aspect, color, odour, taste), uniformity, $\mathrm{pH}$, viscosity, conductivity, microbiological contamination, rupture point, saponification index, alcoholic content, active principle content, among others (Baby et al., 2004; Brasil, 2004).

A comparative study between the free and modified enzymes has aimed to apply the latter as raw material in cosmetic and pharmaceutical formulations (Traversa et al., 2003; Sim et al., 2003; Pieper, Caliri, 2003).

The aim of this research is to assess the physical, physicochemical and chemical stability of free and modified papain incorporated in cosmetic formulations - gels (reference preparation) and emulsions - in order to enable the industry-scale production of formulations in a stable manner that makes them viable for commercialization.

\section{MATERIAL AND METHODS}

\section{Stability test}

We developed seventeen $\mathrm{O} / \mathrm{W}$ emulsions containing $0.8 \%(\mathrm{w} / \mathrm{w})$ papain (obtained from Wallerstein, Brazil) (Traversa et al., 2007). They were composed of: emulsifying wax NF (purchased from Chemyunion - Brazil); paraffinum liquidum (purchased from Mapric - Brazil); myristyl lactate and isopropyl palmitate (gifts from Croda, Brazil); ethylparaben, isobutylparben, methylparaben, propylparaben (and) phenoxyethanol; decyl oleate and hydroxylated milk glycerides (gift from Ionquímica, Brazil); dibutyl adipate (gift from Cognis, Brazil); ammonium acryloyldimethyltaurate/VP copolymer (gift from Clariant, Brazil); carbomer and acrylates/C10-30 alkyl acrylate crosspolymer (purchased from Noveon Consumer Specialties Lubrizol, Brazil); hydroxyethylcellulose (purchased from Galena, Brazil); propylene glycol (purchased from Cosmotec, Brazil); and cyclopentasiloxane (gift from Dow Corning - Brazil). The quantitative composition ( $\% \mathrm{w} / \mathrm{w})$ of the formulations is described on Tables I and II.

The formulations were evaluated 24 hours after their 
TABLE I - Qualitative and quantitative composition of the formulations containing $0.8 \%$ of papain, prepared for macroscopic evaluation and sensorial aspect (1 to 7 )

\begin{tabular}{|c|c|c|c|c|c|c|c|}
\hline \multirow[t]{2}{*}{ COMPONENTS (INCI Name *) } & \multicolumn{7}{|c|}{$\%(w / w)$} \\
\hline & 1 & 2 & 3 & 4 & 5 & 6 & 7 \\
\hline \multicolumn{8}{|l|}{ Oil phase } \\
\hline Emulsifying Wax NF & 1.5 & 1.5 & 1.5 & 1.5 & 1.5 & 1.5 & 1.5 \\
\hline Paraffinum Liquidum & 0.5 & 0.5 & 0.5 & 0.5 & 0.5 & 0.5 & 0.5 \\
\hline Myristyl Lactate & 1.0 & 1.0 & 1.0 & 1.0 & 1.0 & 1.0 & 1.0 \\
\hline Isopropyl Palmitate & 2.0 & 2.0 & 2.0 & 2.0 & 2.0 & 2.0 & 2.0 \\
\hline Decyl Oleate & 2.0 & 2.0 & 2.0 & 2.0 & 2.0 & 2.0 & 2.0 \\
\hline Hydroxylated Milk Glycerides & 0.5 & 0.5 & 0.5 & 0.5 & 0.5 & 0.5 & 0.5 \\
\hline Dibutyl Adipate & 1.0 & 1.0 & 1.0 & 1.0 & 1.0 & 1.0 & 1.0 \\
\hline Ammonium Acryloyldimethyltaurate/VP copolymer & 1.0 & 1.5 & - & - & - & - & - \\
\hline \multicolumn{8}{|l|}{ Aqueous phase } \\
\hline Carbomer & - & - & 1.0 & 1.5 & - & - & - \\
\hline Acrylates/C10-30 alkyl acrylate crosspolymer & - & - & - & - & 1.0 & 0.25 & 0.5 \\
\hline Hydroxyethylcellulose & - & - & - & - & - & - & - \\
\hline Propylene glycol & 2.5 & 2.5 & 2.5 & 2.5 & 2.5 & 2.5 & 2.5 \\
\hline Water q.s.p. & 100.0 & 100.0 & 100.0 & 100.0 & 100.0 & 100.0 & 100.0 \\
\hline \multicolumn{8}{|l|}{ Additional phase } \\
\hline $\begin{array}{l}\text { Ethylparaben; isobutylparaben; methylparaben; } \\
\text { phenoxyethanol; propylparaben }\end{array}$ & 0.5 & 0.5 & 0.5 & 0.5 & 0.5 & 0.5 & 0.5 \\
\hline Cyclopentasiloxane & 2.5 & 2.5 & 2.5 & 2.5 & 2.5 & 2.5 & 2.5 \\
\hline Essence & 0.5 & 0.5 & 0.5 & 0.5 & 0.5 & 0.5 & 0.5 \\
\hline
\end{tabular}

(-) No added components, (*) INCI Name (International Nomenclature of Cosmetic Ingredient, INDEX ABC, 2009)

preparation. The macroscopically stable ones were submitted to the Preliminary Stability Test, which consisted of centrifugation and thermal stress tests. Organoleptical characteristics (aspect, color and odor) and $\mathrm{pH}$ were evaluated at the beginning and at the end of each test, at room temperature (Roland et al., 2003; Brasil, 2004).

The formulations without important alterations underwent the Accelerated Stability Test, and were submitted to the same conditions and evaluation periods described in the literature 24 hours after preparation and incorporation of papain and cysteine. Organoleptical characteristics, $\mathrm{pH}$, apparent viscosity and conductivity values were noted (Brasil, 2004; Baby et al., 2004).

After the Accelerated Stability Test, two formulations were selected for the Normal Stability Test (Table III). These were submitted to the same evaluation conditions and periods described in the literature 24 hours after their preparation under the abovementioned conditions. Organoleptic characteristics, $\mathrm{pH}$ variation, apparent viscosity, conductivity and papain activity were evaluated (Brasil, 2004; Baby et al., 2004).

\section{Enzyme modification}

The polyethylene glycol (PEG) used for the pegylation of the enzyme was modified with succinyl anhydride and activated with 1-hydroxypyrrolidine-2,5-dione (NHS) and $N, N^{\prime}$-dicyclohexylcarbodiimide (DCC), forming the methoxypolythylene glycol succinimidylsuccinate (SS-PEG) shown in Scheme 1. This derivative reacts preferably with the free amines of the enzyme lysine side chain. The reaction of SS-PEG with papain was performed in $\mathrm{pH} 7.5$ buffer at $15.0^{\circ} \mathrm{C}$ for a period of 12 hours, under magnetic stirring in a glass reactor (Scheme 2). Papain concentration was 5\% (w/v) (Holtsberg et al., 2002; Matsuyama et al., 1991).

As a control for the incorporation of the polyethylene glycol in papain, analysis of poliacrylamide gel electrophoresis and dosage of the polyethylene glycol group incorporated in the papain structure were performed by spectrophotometry with trimethyl benzene sulphonic acid (TNBS) (Habeeb, 1966). 
TABLE II - Qualitative and quantitative composition of the pre-formulations containing $0.8 \%$ of papain, prepared for macroscopic evaluation and sensorial aspect (8 to 17$)$

\begin{tabular}{|c|c|c|c|c|c|c|c|c|c|c|}
\hline \multirow[t]{2}{*}{ COMPONENTS (INCI Name*) } & \multicolumn{10}{|c|}{$\%(\mathrm{w} / \mathrm{w})$} \\
\hline & 8 & 9 & 10 & 11 & 12 & 13 & 14 & 15 & 16 & 17 \\
\hline \multicolumn{11}{|l|}{ Oil Phase } \\
\hline Emulsifying Wax NF & 1.5 & 1.5 & 1.5 & 1.5 & 1.5 & 1.5 & 1.5 & 1.5 & 1.5 & 3.0 \\
\hline Paraffinum Liquidum & 0.5 & 0.5 & 0.5 & 0.5 & 0.5 & 0.5 & 0.5 & 0.5 & 0.5 & 0.5 \\
\hline Myristyl Lactate & 1.0 & 1.0 & 1.0 & 1.0 & 1.0 & 1.0 & 1.0 & 1.0 & 1.0 & 1.0 \\
\hline Isopropyl Palmitate & 2.0 & 2.0 & 2.0 & 2.0 & 2.0 & 2.0 & 2.0 & 2.0 & 2.0 & 2.0 \\
\hline Decyl Oleate & 2.0 & 2.0 & 2.0 & 2.0 & 2.0 & 2.0 & 2.0 & 2.0 & 2.0 & 2.0 \\
\hline Hydroxylated Milk Glycerides & 0.5 & 0.5 & 0.5 & 0.5 & 0.5 & 2.0 & 2.0 & 2.0 & 2.0 & 2.0 \\
\hline Dibutyl Adipate & 1.0 & 1.0 & 1.0 & 1.0 & 1.0 & 1.0 & 1.0 & 1.0 & 1.0 & 1.0 \\
\hline $\begin{array}{l}\text { Ammonium Acryloyldimethyltaurate/VP } \\
\text { copolymer }\end{array}$ & - & 0.5 & 1.0 & 2.0 & - & - & - & - & - & - \\
\hline \multicolumn{11}{|l|}{ Aqueous phase } \\
\hline Carbomer & - & - & - & - & 0.5 & - & - & - & - & - \\
\hline $\begin{array}{l}\text { Acrylates/C10-30 alkyl acrylate } \\
\text { crosspolymer }\end{array}$ & 1.5 & - & - & - & - & 0.5 & 0.25 & - & - & - \\
\hline Hydroxyethylcellulose & - & 0.5 & 0.5 & 0.5 & 0.5 & 0.5 & 0.5 & 0.5 & 1.0 & - \\
\hline Propylene glycol & 2.5 & 2.5 & 2.5 & 2.5 & 2.5 & 2.5 & 2.5 & 2.5 & 2.5 & 2.5 \\
\hline Water q.s.p. & 100.0 & 100.0 & 100.0 & 100.0 & 100.0 & 100.0 & 100.0 & 100.0 & 100.0 & 100.0 \\
\hline \multicolumn{11}{|l|}{ Additional Phase } \\
\hline $\begin{array}{l}\text { Ethylparaben; isobutylparaben; } \\
\text { methylparaben; phenoxyethanol; } \\
\text { propylparaben }\end{array}$ & 0.5 & 0.5 & 0.5 & 0.5 & 0.5 & 0.5 & 0.5 & 0.5 & 0.5 & 0.5 \\
\hline Cyclopentasiloxane & 2.5 & 2.5 & 2.5 & 2.5 & 2.5 & 2.5 & 2.5 & 2.5 & 2.5 & 2.5 \\
\hline Essence & 0.5 & 0.5 & 0.5 & 0.5 & 0.5 & 0.5 & 0.5 & 0.5 & 0.5 & 0.5 \\
\hline
\end{tabular}

(-) No added components, $(*)$ INCI Name (International Nomenclature of Cosmetic Ingredient, INDEX ABC, 2009)

\section{Papain activity - method validation}

Benzyloxycarbonyl-phenylalanyl-arginine 7-amido4-methylcoumarin was used as substrate in the assay that was performed in microplates. The production of 7-amido4-methylcoumarin (7-MCA) over different periods of time was used to quantify the concentration of papain in pharmaceutical forms (gel and emulsion). This method presented a linear relationship between papain concentration and rate of 7-MCA production $(\mathrm{R}=0.9974)$. It also presented an estimated limit of detection (LOD) of 0.040 USP $\mathrm{mL}^{-1}$; an estimated limit of quantification (LOQ) of 0.12 USP. $\mathrm{mL}^{-1}$; a precision (RSD \%) ranging from 2.7 to 5.0 and an accuracy (E\%) ranging from 95.3 to 96.7 . The components of the topical formulation did not interfere in papain detection (Kanaoka, Takahashi, 1977; Brasil, 2003; Pinto et al., 2007).

\section{RESULTS AND DISCUSSION}

\section{Preliminary tests}

The preliminary tests enabled the identification of signs of instability in six of the formulations submitted to the thermal stress and centrifugation tests, such as phase separation, formation of lumps and changes in odour. Four formulations were approved and subsequently submitted to the Accelerated Stability Test.

The results obtained indicated that the formulation containing polymer Acrylates/C10-30 Alkyl Acrylate Crosspolymer did not remain stable after the preliminary tests, probably because the preparations require different elaboration techniques concerning stirring speed and dispersion time.

The behavior of an emulsion submitted to cen- 
TABLE III - Formulations submitted to the Normal Stability Test. Gel (reference), preparations 2 and $\mathbf{3}[0.8 \%$ (w/w) of non-modified papain and $0.16 \%(\mathrm{w} / \mathrm{w})$ of cysteine], and preparation $2 \mathrm{M}$ with $22.06 \%(\mathrm{w} / \mathrm{v})$ of modified papain and $0.16 \%(\mathrm{w} / \mathrm{w})$ of cysteine

\begin{tabular}{|c|c|c|c|c|}
\hline \multicolumn{5}{|l|}{ Formulation } \\
\hline \multirow[t]{2}{*}{ Components (INCI Name*) } & Gel & 2 & 3 & $2 \mathrm{M}$ \\
\hline & \multicolumn{4}{|c|}{$\% \mathrm{w} / \mathrm{w}$} \\
\hline \multicolumn{5}{|l|}{ Oil Phase } \\
\hline Emulsifying Wax NF & - & 1.5 & 1.5 & 1.5 \\
\hline Paraffinum Liquidum & - & 0.5 & 0.5 & 0.5 \\
\hline Myristyl Lactate & - & 1.0 & 1.0 & 1.0 \\
\hline Isopropyl Palmitate & - & 2.0 & 2.0 & 2.0 \\
\hline Decyl Oleate & - & 2.0 & 2.0 & 2.0 \\
\hline Hydroxylated Milk Glycerides & - & 0.5 & 0.5 & 0.5 \\
\hline Dibutyl Adipate & - & 1.0 & 1.0 & 1.0 \\
\hline Ammonium Acryloyldimethyltaurate/VP copolymer & - & 1.5 & - & 1.5 \\
\hline \multicolumn{5}{|l|}{ Aqueous phase } \\
\hline Carbomer & 0.6 & - & 1.0 & - \\
\hline Propylene glycol & 5.0 & 2.5 & 2.5 & 2.5 \\
\hline Water q.s.p. & 100 & 100 & 100 & 100 \\
\hline \multicolumn{5}{|l|}{ Additional Phase } \\
\hline Methylparaben & 0.3 & 0.3 & 0.3 & 0.3 \\
\hline Ethylparaben; isobutylparaben; methylparaben; phenoxyethanol; propylparaben & - & 0.5 & 0.5 & 0.5 \\
\hline Cyclopentasiloxane & - & 2.5 & 2.5 & 2.5 \\
\hline Essence & - & 0.5 & 0.5 & 0.5 \\
\hline Free papain & 0.8 & 0.8 & 0.8 & - \\
\hline Modified papain & - & - & - & 22.06 \\
\hline L-cysteine $\mathrm{HCl}$ monohydrate & 0.16 & 0.16 & 0.16 & 0.16 \\
\hline
\end{tabular}

(-) No added components, $(*)$ INCI Name (International Nomenclature of Cosmetic Ingredient, INDEX ABC, 2009)

trifugation depends on the difference in densities of the oil and aqueous phases and also on the interfacial resistance between the phases. Thermal stress accelerates the degradation process of components in the preparations. After centrifugation, the formulation without thickening, emulsifying or film-forming agents did not withstand the test conditions. This result was expected, because the concentration of the self-emulsifying component was inferior to that recommended by the manufacturer $(2.0 \%)$. The formulation that contained only a cellulose derivative (hydroxyethylcellulose) also did not withstand the test, what is in accordance with the experiments performed by Velasco et al. (1999) and Traversa et al. (2003), in which the gel prepared with a cellulose derivative presented lower stability than that of the gel prepared with carbomer (Velasco et al., 1999; Roland et al., 2003; Traversa et al., 2003).

The formulations that did not present signs of insta- bility after the Preliminary Test were the ones with polymers ammonium acryloyldimethyltaurate/VP copolymer (formulations 2 and 10, as shown in Tables I and II) and carbomer (formulations 3 and 12, as shown in Tables I and II). These presented only with odour modifications after the thermal stress test, due to enzyme degradation at high temperatures, causing the subsequent release of a characteristic sulfur odour (Tables I and II). The polymers may have increased the emulsion stability because they reduced the phase separation speed.

\section{Accelerated stability test}

This Test allowed us to choose the most stable preparations under the different environmental conditions. Formulations 10 and 12 (Table II) contained not only the polymers ammonium acryloyldimethyltaurate/VP copolymer and carbomer but also hydroxyethylcellulose, 

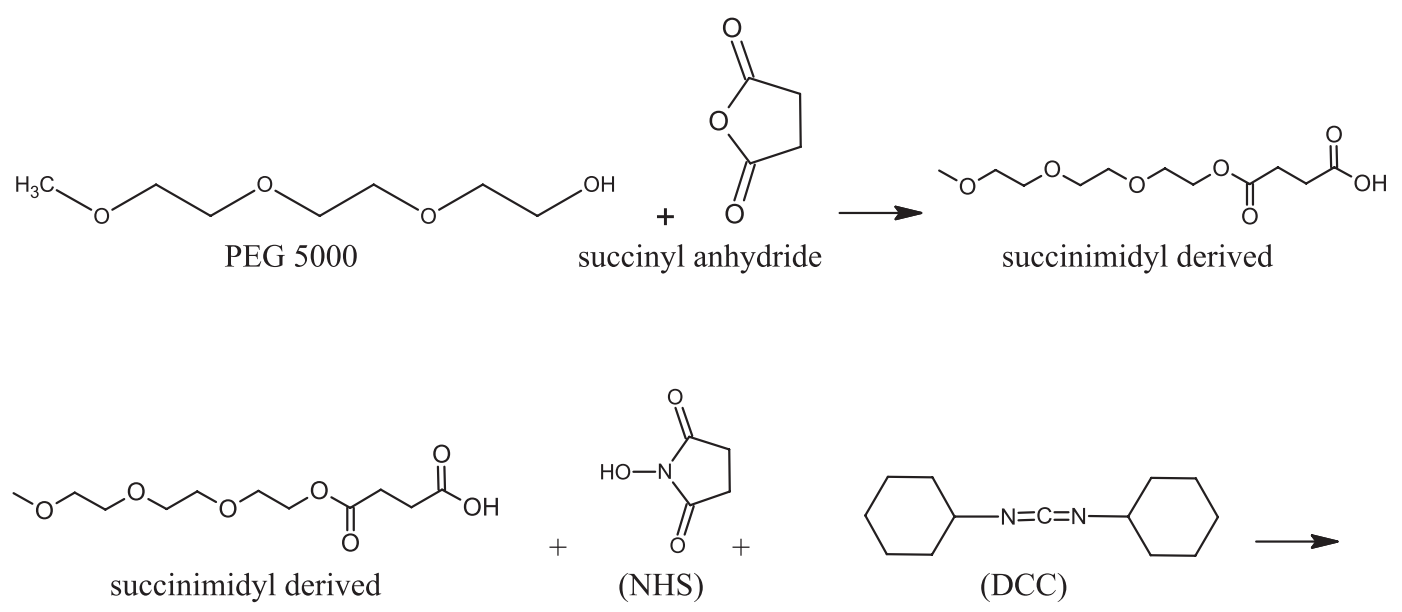<smiles>COCCOCCOCCOC(=O)CCC(=O)ON1C(=O)CCC1=O</smiles>

(SS-PEG)

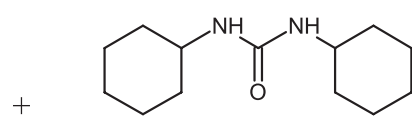

1,3-dicyclohexylurea

SCHEME 1 - Obtention of the PEG activated derivative, used to modify the papain.<smiles>CNCPN1CCC(=O)N1OC(=O)CCC(=O)OCCOCCOCCOC</smiles>

Papain complex

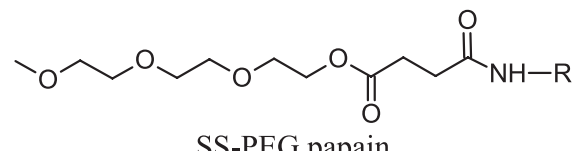

SCHEME 2 - Peglylation of papain.

and presented the highest variations in organoleptical characteristics, $\mathrm{pH}$, apparent viscosity and conductivity.

These results show that the formulations ( 2 and 3 ) with only one of the previously mentioned synthetic polymers tended to have a better performance when compared to the ones containing a cellulose derivative. Formulations 2 and 10 (Tables I and II) presented the most altered $\mathrm{pH}$ values, with a maximum of 0.6 units under conditions of $45.0 \pm 2.0 /-10.0 \pm 1.0^{\circ} \mathrm{C}$ (laboratory oven/freeze cycle). This behavior was expected, due to the drastic conditions for formulations containing enzymes. Despite the variations, $\mathrm{pH}$ values were suitable for enzymatic activity (Velasco et al., 1999; Merck Index, 2006).

There was a variation in apparent viscosity at
$45.0 \pm 2.0^{\circ} \mathrm{C}$ with a $40 \%$ and $35 \%$ decrease for formulations 12 and 10, respectively. This result was also expected because of enzyme degradation under high temperatures, which may interfere in formulation viscosity. The concentrations of ammonium acryloyldimethyltaurate/VP copolymer $(1.0 \%$ $\mathrm{w} / \mathrm{w})$ and carbomer $(0.5 \% \mathrm{w} / \mathrm{w})$ in these preparations were not enough to maintain their viscosity profiles, and neither was the presence of hydroxyethylcellulose. Traversa et al. (2003) also observed the instability of preparations with papain in the presence of hydroxyethylcellulose. They prepared a papain gel $(0.8 \% \mathrm{w} / \mathrm{w})$ which underwent the centrifugation test (Preliminary Stability Test), which led to the formation of crystals and enzyme decantation.

There was also a variation in conductivity. The highest difference appeared under the conditions of $-10.0 \pm 1.0{ }^{\circ} \mathrm{C}$ (freezer), with a tendency for augmentation in all formulations. The highest variation $(40 \%)$ was founf for formulation 10 , whilst the other formulations presented variations below $25 \%$. Electric conductivity is important to monitor the stability of $\mathrm{O} / \mathrm{W}$ emulsions and to verify the integrity of the external phase, mainly for emulsions that are stored for long periods of time. Results showed that formulation 10 did not present external phase integrity when exposed to $-10.0 \pm 1.0^{\circ} \mathrm{C}$ (freezer), which is considered as a drastic condition (Griffin et al., 1967; Latreille, Paquin, 1990).

Due to the results of the Accelerated Stability Test, formulations 2 and 3 were selected for the Normal Stability Test. 


\section{Normal stability test}

The formulations evaluated ( 24 hours after the preparation, for stabilization) during the Normal Stability Test were:

- 2 with papain;

- 3 with papain;

- $\quad 2 \mathrm{M}$, (same as formulation 2) with modified papain;

- $\quad$ papain gel (reference formulation, stored under refrigeration conditions $\left(5.0 \pm 1.0^{\circ} \mathrm{C}\right)$ ).

Figure 1 shows the variation in papain activity during the Normal Stability Test at $5.0 \pm 1.0^{\circ} \mathrm{C}$.

Normal Stability Test - activity (\%) - $5 \pm 1.0^{\circ} \mathrm{C}$

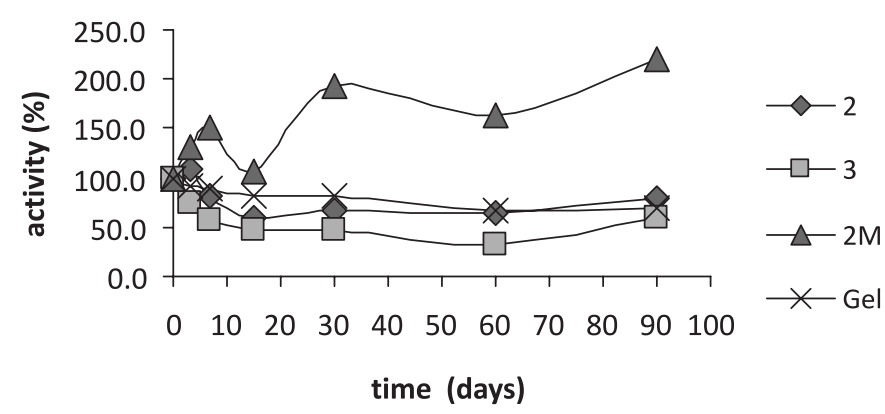

FIGURE 1 - Papain activity variation (\%) for formulations 2 , $3,2 \mathrm{M}$ and $\mathrm{Gel}$, under the conditions of $5.0 \pm 1.0^{\circ} \mathrm{C}$, during the Normal Stability Test.

According to Figure 1, at $5.0 \pm 1.0^{\circ} \mathrm{C}$ (refrigerator), the papain gel (reference sample) had a slower initial decrease in enzymatic activity than the emulsions containing ammonium acryloyldimethyltaurate/VP copolymer and carbomer (formulations 2 and 3 , respectively) until the $30^{\text {th }}$ day, and maintained $70 \%$ of remaining activity. This result may have occurred because of the presence of Emulsifying Wax NF (non-ionic emulsifier) in the two last preparations, which may have interacted with the enzyme, thus reducing its stability. As to the gel, the vehicle is simpler and includes a polymeric gelifying agent that stabilizes the enzyme. After this time, all formulations (2, 3 and Gel) behaved similarly, with similar differences in activity (\%). After 90 days, all formulations obtained values of approximately $70 \%$. The same behavior was observed by Velasco et al. (1999), who studied papain incorporated into gel formulations. They have stated that the preparation with carbomer retained approximately $70 \%$ of the initial activity after 57 days at $5.0 \pm 1.0{ }^{\circ} \mathrm{C}$ (refrigerator).

Figure 2 represents the variation in papain activity during the Normal Stability Test at $22 \pm 2.0^{\circ} \mathrm{C}$.
Normal Stability Test - activity (\%) - $22 \pm 2.0^{\circ} \mathrm{C}$

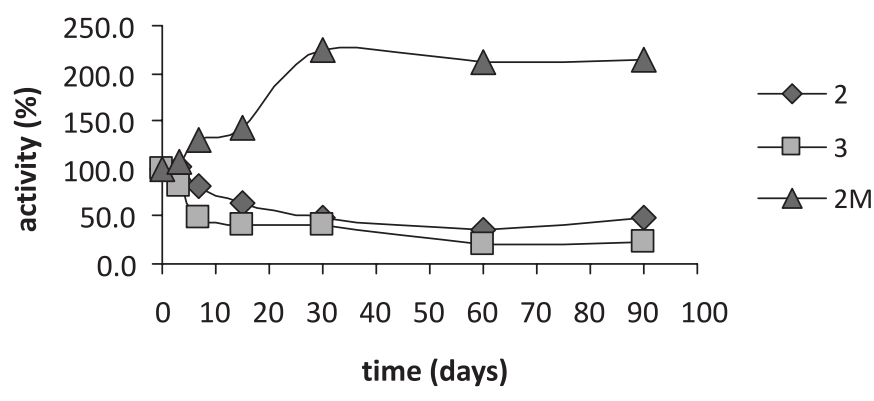

FIGURE 2 - Papain activity variation (\%) for formulations 2 , $3,2 \mathrm{M}$ and Gel at $22 \pm 2.0^{\circ} \mathrm{C}$ during the Normal Stability Test.

Formulations 2 and 3 presented different decreasing profiles when exposed to temperatures of $22.0 \pm 2.0$ ${ }^{\circ} \mathrm{C}$ (Figure 2). Formulation 3 was found to have a papain activity decrease of almost $50 \%$ at the $7^{\text {th }}$ day and $80 \%$ at the $90^{\text {th }}$ day. Formulation 2 was found to have papain activity reduced by $50 \%$ at the $30^{\text {th }}$ day and by approximately $60 \%$ at the $90^{\text {th }}$ day.

Figure 3 shows the variation in papain activity during the Normal Stability Test at $40 \pm 2.0^{\circ} \mathrm{C}$.

\section{Normal Stability Test - activity (\%) - $40 \pm 2.0^{\circ} \mathrm{C}$}

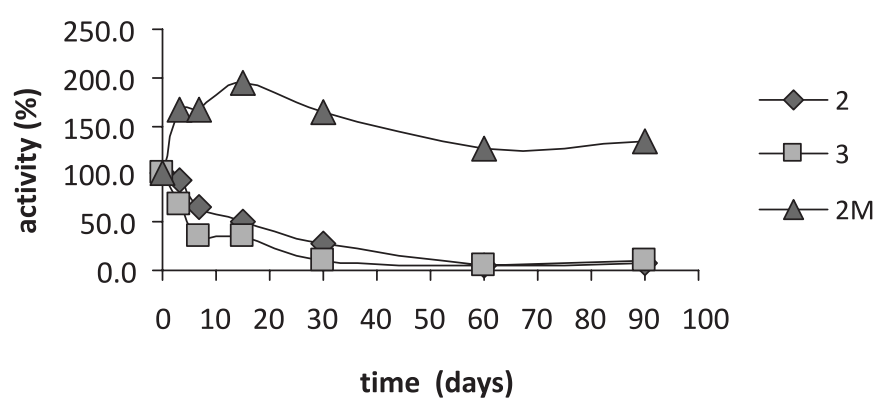

FIGURE 3 - Papain activity variation (\%) for formulations 2, $3,2 \mathrm{M}$ and Gel at $40 \pm 2.0^{\circ} \mathrm{C}$ during the Normal Stability Test.

Formulation 3 presented approximately half of the remaining activity value at $40.0 \pm 2.0^{\circ} \mathrm{C}$, when compared to formulation 2 (Figure 3 ) until the $30^{\text {th }}$ day. After this period, the profile became similar. After 60 days, both formulations possessed papain activity inferior to $10 \%$ in relation to the initial value. This was maintained until the end of the test. These results were already expected, as the increase in temperature accelerated the process of enzyme decomposition (Rajalakshmi, Sundaram, 1995).

The activity of the enzyme incorporated in formulations 2, 3 and gel was affected by the temperature increase 
during the Normal Stability Test. After 90 days, the results were: (1) $40.0 \pm 2.0^{\circ} \mathrm{C}$ - the remaining activity for formulations 2 and 3 was inferior to $10 \%$; (2) $22.0 \pm 2.0{ }^{\circ} \mathrm{C}$ - data obtained were $47 \%$ and $23 \%$, respectively; (3) $5.0 \pm 1.0^{\circ} \mathrm{C}$ - all formulations $(2,3$ and Gel) presented with a remaining activity of approximately $70 \%$. The preparations presented minimum activity loss under the last temperature value, which concurs with the literature (Velasco et al., 1999; Rajalakshmi, Sundaram, 1995).

The modified enzyme presented an increase in enzymatic activity over the course of time for all studied conditions. After papain pegylation and subsequent enzymatic activity analysis, we noticed a decrease to $44 \%$ when compared to the unmodified enzyme. This difference was taken into account when the modified enzyme was incorporated in the formulation. Due to the results obtained for the Normal Stability Test, it was verified that the enzyme presented some enzymatic activity loss but this loss may not have been definitive.

In the Normal Stability Test, at $40.0 \pm 2.0^{\circ} \mathrm{C}$ (Figure 3 ), there was an activity of $200 \%$ on the $15^{\text {th }}$ day comparing to the initial value with a further decrease to $133 \%$ on the $90^{\text {th }}$ day. At $22.0 \pm 2.0{ }^{\circ} \mathrm{C}$ (Figure 2), this value was obtained after 30 days and kept until the $90^{\text {th }}$. At $5.0 \pm 1.0^{\circ} \mathrm{C}$ (Figure 1), this value was only reached after 90 days. This behavior could be explained because the modified enzyme is unavailable to exert its action at the beginning, and, as time decurred and temperature acted, the enzymatic activity of papain pegylated was changed.

This behavior was similar to the one found by Rajalakshmi \& Sundaram (1995). They modified papain with polymeric sucrose and observed the enzyme when exposed to a $8 \mathrm{M}$ urea solution at $37^{\circ} \mathrm{C}$ for 24 hours. These conditions were critical for papain due to the high temperature and to the presence of the urea solution, acting as an inhibitive agent. In this research it could be observed that, during a 4-hour period, enzyme activity increased by $170 \%$ compared to the initial activity (Rajalakshmi, Sundaram, 1995).

Miyamoto et al. (2004) have stabilized and conjugated papain with hydrosoluble phospholipidic polymeric chains containing a reactive terminal group. The enzyme was kept at $25{ }^{\circ} \mathrm{C}$ for activity analysis. Enzymatic activity was found to have increased, and it reached $150 \%$ of the initial value after 28 days. This phenomenon was explained by the formation of conjugate papain aggregates that are released over the course of time.

The objective of the preparation with modified enzyme was to elevate enzyme stability and to promote its gradual liberation in the action site, thus enhancing its therapeutical/cosmetic efficacy.
Among the temperatures of the Normal Stability Test, the most stable for the formulation with modified papain was $22.0 \pm 2.0{ }^{\circ} \mathrm{C}$ (Figure 2), at which an activity increase was observed until the $30^{\text {th }}$ day, with further stabilization. Under the refrigerator conditions $\left(5.0 \pm 1.0^{\circ} \mathrm{C}\right)$, the enzyme did not present a stabilization profile until the $90^{\text {th }}$ day. At $40.0 \pm 2.0^{\circ} \mathrm{C}$, there was a variation in enzymatic activity, with a fast increase in the first 15 days and a subsequent lack of stabilization in the activity profile. It was noticed that $22.0 \pm 2.0^{\circ} \mathrm{C}$ was the most suitable condition for modified papain. This highlights the advantage of modified papain, when compared to its free form, which requires refrigerator conditions $\left(5.0 \pm 1.0^{\circ} \mathrm{C}\right)$ for suitable storage.

Formulations 2 and $2 \mathrm{M}$ possessed the lowest variations concerning $\mathrm{pH}$ (approximately $15 \%$ at $-40.0 \pm 2.0^{\circ} \mathrm{C}$ ), as temperature increase degrades the enzyme and alters $\mathrm{pH}$ values. Under the other conditions, $\mathrm{pH}$ variations were inferior to $7.0 \%$, but the values were considered suitable for papain enzymatic activity (5.0 to 7.0) (Velasco et al., 1999; Merck Index, 2006).

As to the viscosity variation for formulation 2 under all conditions, no oscillation exceeded $20 \%$ in relation to the initial conditions, with a tendency to increase. The polymeric emulsifying agent in this preparation was Ammonium Acryloyldimethyltaurate/VP copolymer. There might have been an interaction between this polymer and the other formulation components, in addition to its degradation by papain. However, this oscillation did not significantly alter the organoleptical characteristics. Despite the variation around $17 \%$ for formulation 3 at $40.0 \pm 2.0^{\circ} \mathrm{C}$, the results were satisfactory at $5.0 \pm 1.0^{\circ} \mathrm{C}$ and $22 \pm 2.0^{\circ} \mathrm{C}$, with variations below $10 \%$. Formulation 2 varied less than $10 \%$ under all conditions. These results indicate the stability of emulsions, concerning the external phase. The likely explanation would be that the polymers maintained their structures during the study, thus avoiding separation of phases (Griffin et al., 1967; Latreille, Paquin, 1990).

\section{CONCLUSION}

Amongst the formulations with $0.8 \%(\mathrm{w} / \mathrm{w})$ nonmodified papain, the emulsion containing carbomer presented the most suitable $\mathrm{pH}$, viscosity and conductivity responses under all temperature conditions $\left(5.0 \pm 1.0{ }^{\circ} \mathrm{C}\right.$; $22.0 \pm 2.0^{\circ} \mathrm{C}, 40.0 \pm 2.0^{\circ} \mathrm{C}$ ), when compared to the emulsion containing the polymer ammonium acryloyldimethyltaurate/VP copolymer.

The activity of the non-modified enzyme during the Normal Stability Test incorporated into the formulations that were kept at $22.0 \pm 2.0{ }^{\circ} \mathrm{C}$ was influenced by the type 
of polymer. The emulsion containing ammonium acryloyldimethyltaurate/VP copolymer maintained approximately two times the enzymatic activity, when compared to the formulation containing carbomer. For the other temperatures, the different polymers did not influence enzyme activity.

Temperature influenced the behavior of non-modified papain activity in the emulsions. At $40.0 \pm 2.0^{\circ} \mathrm{C}$ there was a faster decrease in enzymatic activity, in the order of approximately $90 \%$ in 90 days.

The storage of the formulations in the refrigerator $\left(5.0 \pm 1.0^{\circ} \mathrm{C}\right)$ was found to be the best condition for emulsions containing $0.8 \%(\mathrm{w} / \mathrm{w})$ of non-modified papain, ammonium acryloyldimethyltaurate/VP copolymer and carbomer.

The method of papain modification with polyethylene glycol altered the release profile and the activity of the enzyme incorporated into the emulsion containing ammonium acryloyldimethyltaurate/VP copolymer, under all conditions assessed. Enzyme stability was higher than in the formulations containing the non-modified enzyme.

The temperature of $22.0 \pm 2.0^{\circ} \mathrm{C}$ was the most suitable for the emulsion containing modified papain and the polymer ammonium acryloyldimethyltaurate/VP copolymer.

\section{ACKNOWLEDGEMENTS}

The authors acknowledge the contribution of Professor Dr. Jose Abrahão Neto, Laboratory of Biotechnology - Industrial Enzymology, Department of Pharmaceutical and Biochemical Technology, Faculty of Pharmaceutical Sciences, University of São Paulo.

\section{REFERENCES}

AFAQ, S.; IQBAL, J. Immobilization and stabilization of papain on chelating sepharose: a metal chelate regenerable carrier. Electron. J. Biotechnol, v.4, 2001. Avaliable at: <http:// www.ejbiotechnology.info/index.php/ejbiotechnology/ article/viewFile/v4n3-1/916>. Accessed on: 01 jun. 2011.

ARNON, R. Papain. Meth. Enzymol., v.19, p.226-244, 1970.

BABY, A.R.; MACIEL, C.P.; ZAGUE, V.; KANEKO, T.M.; CONSIGLIERI, V.; VELASCO, M.V.R. Ensaios aplicados aos produtos cosméticos e dermatológicos emulsionados. Int. J. Pharm. Comp. (braz.edittion), v.6, p.130-139, 2004.
BRASIL. Ministério da Saúde. Agência Nacional de Vigilância Sanitária Resolução RE n. 899, de 29 de maio de 2003. Guia para validação de métodos analíticos e bioanalíticos. Available at: <http://e-legis.anvisa.gov.br/leisref/public/ showAct.php?mode=PRINT_VERSION\& id=15132> . Accessed on: 11 dez. 2010.

BRASIL. Ministério da Saúde. Agência Nacional de Vigilância Sanitária. Guia de estabilidade de produtos cosméticos. Brasília, 2004. 47 p. (Séries Temáticas: Qualidade 1).

EL-KADI, K.N.; RAWLINGS, A.V.; FEINBERG, C.; WATKINSON, A.; NUNN, C.C.; BATTAGLIA, A.; CHANDAR, P.; POCALYKO, N.R.D.J. Broad specificity alkaline proteases efficiently reduce the visual scaling associated with soap-induced xerosis. Arch. Dermatol., v.293, p.500-507, 2001.

GRIFFIN, W.C.; LYNCH, M.J.; LATHROP, L.B. Emulsions, part one. Drug Cosmet. Ind., v.231, p.170-173, 1967.

HABEEB, A.F.S.A. Determination of free amino groups in proteins by trinitrobenzenesulfonic acid. Anal. Biochem., v.14, p.328-336, 1966.

HOLTSBERG, F.W.; ENSOR, C.M.; STEINER, M.R., BOMALASKI, J.S.; CLARK, M.A. Poly(ethylene glycol) (PEG) conjugated arginine deiminase: effects of PEG formulations on its pharmacological properties. J. Control. Release., v. 80, p.259-271, 2002.

ÍNDEX ABC. Ingredientes para a indústria de produtos de higiene pessoal cosméticos e perfumes. 3.ed. São Paulo: Pharmabooks, 2009. $1460 \mathrm{p}$.

KANAOKA, Y.; TAKAHASHI, T. Syntesis of a Key fluorogenic amide, L-arginine-4methylcoumaryl-7-amide (L-ArgMCA) and its derivatives. Fluorescence assays for trypsin and papain. Chem. Pharm. Bull., v.25, p.3126-3128, 1977.

KANG, C.K.; WARNER, W.D. Tenderization of meat with papayn latex proteases. J. Food Sci., v.39, p.812-818, 1974.

LATREILLE, B.; PAQUIN, P. Evaluation of emulsion stability by centrifugation with condutivity measurementes. J. Food Sci., v.55, p.1666-1668, 1990. 
LI, M.; SU, E.; YOU, P.; GONG, X.; SUN, M.; XU, D.; WEI, D. Purification and In Situ Immobilization of Papain with Aqueous Two-Phase System. PLoS One, v. 5, 2010. Avaliable at: < http://www.ncbi.nlm.nih.gov/pmc/articles/ PMC3001450/pdf/pone.0015168.pdf>. Access 20 may 2011.

LOPES, P.S.; RUA, G.W.R.; BABY, A.R.; PINTO, C.A.S.O.; WATANABE, L.; VELASCO, M.V.R.; KANEKO, T.M. In vitro safety assessment of papain on human skin: a qualitative light and Transmission Electron Microscopy (TEM) study. Rev. Bras. Cienc. Farm., v.44, p.151-156, 2008 .

LOPES, P.S.; YAMAMOTO, J.K.; PINTO, C.A.S.O.; TAKANO, C.Y.; VELASCO, M.V.R.; CONSIGLIERI, V.O.; KANEKO, T.M. Validação de metodologia analítica de avaliação da atividade da papaína. Rev. Bras. Cienc. Farm., v.39, suppl.3, p.214-216, 2003.

MARTINDALE. The Complete Drug Reference. 36.ed. London: Pharmaceutical Press, 2009. p.1647-1648.

MATSUYAMA, H.; TAGUCHI, R.; IKEZAWA, H. Phospholipase D modified with polyethylene glycol derivative. Chem. Pharm. Bull., v.39, p.743-746, 1991.

MERCK INDEX. An encyclopedia of chemicals, drugs, and biologicals. 14.ed. Whitehouse Station: Merck, 2006. $2564 \mathrm{p}$.

MIYAMOTO, D.; WATANABE, J.; ISHIHARA, K. Highly stabilized papain conjugated with water-soluble phospholipids polymer chain having a reacting terminal group. J. Appl. Polym. Sci., v.91, p.827-832, 2004.

PIEPER, B.; CALIRI, M.H. Nontraditional wound care: A review of the evidence for the use of sugar, papaya/papain, and fatty acids. J. Wound. Ostomy. Cont., v.30, p.175-183, 2003.

PINTO, C.A.S.O. ; GREEN, D.; BABY, A.R.; RUAS, G.W.; KANEKO, T.M.; MARANA, S.R.; VELASCO, M.V.R. Determination of papain activity in topical dosage forms: single laboratory validation assay. Lat. Am. J. Pharm., v.26, p.771-775, 2007.

RAJALAKSHMI, N.; SUNDARAM, P.V. Stability of native and covalently modified papain. Protein. Eng., v.8, p.10391047, 1995.
ROLAND, I.; PIEL G.; DELATTRE, L.; EVRARD, B. Systematic characterization of oil-in-water emulsions for formulation design. Int. J. Pharm., v.263, p.85-94, 2003.

SASMITO, T.; DEMEESTER, J.; BRACKE, M. Review on the production, properties and uses of papain. Pharm. Tijdschr. Belg., v.59, p.149-158, 1982.

SIM, Y.C.; LEE, S.G.; LEE, D.C.; KANG, B.Y.; PARK, K.M.; LEE, J.Y.; KIM, M.S.; CHANG, I.S.; RHEE, J.S. Stabilization of papain and lysozyme for application to cosmetic products. Biotechnol. Lett., v.22, p.137-140, 2000.

SIM, Y.C.; NAM, Y.S.; SHIN, Y.H.; SHIN, E.; KIM, S.; CHANG, I.S.; RHEE, J.S. Proteolytic enzyme conjugated to SC-glucan as an enzymatic transdermal drug penetration enhancer. Pharmazie., v.58, p.252-256, 2003.

SZABÓ, A.; KOTORMÁN, M.; LACZKÓ, I.; SIMON, M. Spectroscopic studies of stability of papain in aqueous organic solvents. J. Mol. Catal. B: Enzym., v.41, p.43-48, 2006.

TRAVERSA, E.; MACHADO-SANTELLI, G.M.; VELASCO, M.V.R. Histological evaluation of hair follicle due to papain's depilatory effect. Int. J. Pharm, v.335, p.163-166, 2007.

TRAVERSA, E.; OTTOLENGHI, A.T.B.; MENEGOTTO, C.P.; MARCONDES, C.P.; MACHADO-SANTELLI, G.M.; KANEKO, T.M.; CONSIGLIERI, V.O.; VELASCO, M.V.R. Desenvolvimento de formulações cosméticas contendo papaína e avaliação de sua eficácia depilatória. Rev. Bras. Cienc. Farm., v.39, p.201-203, 2003.

VELASCO, M.V.R.; RODRIGUES, L.B.; DAZZI, C.; YAMAMOTO, J.K.; KANEKO, T.M. Avaliação da estabilidade da solução de papaína $2 \%$ p/v pelo método da coagulação do leite. Rev. Farm. Quim., v.32, p.8-13, 1999.

Received for publication on $23^{\text {rd }}$ June 2011 Accepted for publication on $19^{\text {th }}$ September 2011 